Book Power in Communication, Sociology and Technology

Ed. Angela Repanovici, Manolis Koukourakis, Tereza Khecyoyan

Series: Philosophy, Communication, Media Sciences

Available online at http://trivent-publishing.eu/

\title{
The Role of Fairy Tales in the Self-Realization Process
}

\author{
Daniela Sorea \\ Department of Social Sciences and Communication \\ Transilvania University of Braşov, Romania, sorea.daniela@unitbv.ro
}

\begin{abstract}
The core of Carl Gustav Jung' theory is the teleological orientation of unconscious processes towards individuation. Archetypes provide psychological information regarding the way in which the individuation process unfolds. The fairy tale reflects the universal, elemental and fundamental structures of the psyche in a language accessible above cultural and ethnical differences. Each fairy tale is associated with a specific type of archetypal behaviour. The fairy tale acts as an initiatory text whose force comes from the emotional load of the hero archetype. It is the most simple and efficient means of transmitting information on the individuating process.
\end{abstract}

Keywords: fairy tales; individuation; archetypes; hero; education; European relations. 


\title{
The Role of Fairy Tales in the Self-Realization Process
}

\author{
Daniela Sorea \\ Department of Social Sciences and Communication \\ Transilvania University of Braşov, Romania
}

\section{Introduction}

In Romanian, the expression "fairy tales" is depreciative and indicates the lack of trust in the statements to which it refers. Using the expression with this meaning correctly signals the status of the fairy tale in the European culture and, by extension, in the Western culture. The phrase and its use sanction to logic of the fantastic employed by fairy tales and this logic is different from the one characteristic of common knowledge or scientific knowledge, both of which are acknowledged by the Western cultural space. In this context, fairy tales are viewed as meaningless.

I believe that such an approach is reductionist and that ignoring the knowledge circulated via fairy tales is detrimental to Westerners. This paper proposes the re-evaluation of fairy tales by interpreting them from the perspective of analytical psychology. It also highlights the archetypal references of some of the main themes found in European fairy tales, their educational usefulness in this context, as well as their usefulness in managing the relations within the European community.

This paper employs the analysis made by Marie-Louise von Franz to some fairy tales collected in Europe. Based on her analysis, I identified, presented and sketched the analysis of some Romanian fairy tales which correspond thematically to those she had focused on. This comparative approach has a two-fold aim: it consolidates the understanding of fairy tales as relevant from an archetypal perspective (since archetypes are generally human), and simultaneously, underlines the local differences of the archetypal contents as significant.

\section{Individuation and archetypes in abyssal psychology}

Based on Freud's ideas, Jung develops analytical or abyssal psychology. He was both the most loved and the most hated and despised disciple of Freud, forging with the latter a relationship that renders itself to a psychological analysis. Theoretically and consciously the clash between the two is owed to Jung's refusal to acknowledge the exclusively sexual character of the libido - the energy of the psyche. The concept of individuation is the key to C. G. Jung's abyssal psychology. Individuation is a process by which the psyche refocuses from its conscious dimension, namely the Ego, onto the Self, that is on the whole psyche made of the conscious and unconscious. It is about refocusing since Jung believes that the Ego begins the differentiation process from the Self, that initially is its intrinsic component, ever since childhood. Thus, the mature Ego returns to its Self with all the essential experiences of an individuation process. The latter is perceived by the various cultures and 
religions as integration/identification with the Universe. ${ }^{1}$ The process itself as potentiality is of instinctual origin. All people are "tailored" to follow an individuation process, but not everybody yields to the instinctual calling, especially the one manifest in the second part of the individuation process and which follows the Ego consolidation through education, career, social status, family building. This second stage consists in a dramatic confrontation ${ }^{2}$ between individuals and archetypes. Archetypes are general human schematic models to tackle the challenges of existence. They are not ready made recipes that can be applied just any time. On the contrary, they are blueprints whose contents are culturally conditioned. ${ }^{3}$ Archetypes populate the collective unconscious, namely the common to all human beings and in-depth layer of the psyche.

The collective unconscious stores a lot of archetypes that activate (in a challenging manner for the individual) when life instances that correspond to them emerge. The main archetypes a person can be confronted with in the second stage of the individuation process are in the following order: the shadow, persona, anima/animus, the Self. The shadow is the archetype of every individual's dark side of the psyche. It corresponds to the content of the personal unconscious described by Freud. Such content is located in the unconscious since consciously managing it is unpleasant and requires a lot of psychic energy. Persona is the archetype of the desirable interface, the mask that people instinctively feel the need to wear in order to agree with their community of origin It is the archetype associated with socialization- considered in the sociology of knowledge as a process of internalizing social experiences. . Anima and animus are counter-sexual archetypes. As previously mentioned, the Self is the archetype of the whole. ${ }^{5}$ One of its many forms under which the latter is to be found in the West is the archetype of God.

Jung believes that fairy tales circulate archetypal content. ${ }^{6}$ They are the result of the endeavor of translating into symbolic images some individuation oriented unconscious processes. Moreover, they reflect elementary and fundamental psychic universal structures.

Marie-Louise von Franz is a researcher from Jung's school of thought and his collaborator. She analytically approached fairy tales and hence, most of the arguments to follow are based on her results presented in her work.

\section{What are fairy tales?}

Fairy tales are takeovers of some individual numinous experiences in the collective consciousness. ${ }^{7}$ From this perspective, they reflect the contents of the collective unconscious in consciousness and are not mere tales of some individuation based experiences. However, not all experiences of this kind become fairy tales. To become so they need to meet some psychic needs of communities. Fairy tales set, amplify, potentiate and relay significant information related to some archetypal psychic dispositions analogous to those of the individuals having had numinous experiences. ${ }^{8}$ The deep emotional intensity

\footnotetext{
${ }^{1}$ Carl Gustav Jung, Gesammelte Werke, 8 (Düsseldorf: Walter-Verlag, 1995)

2 Michael Palmer, Freud and Jung on Religion (London: Routledge, 1997).

3 Anthony Stevens, On Jung (London: Routledge, 1990).

${ }^{4}$ Ioana Anisa Atudorei, Emoțiile morale in contextul crizei din România [Moral emotions in the context of the crisis in Romania] (Cluj-Napoca: Presa Universitară Clujeană, 2016).

5 Carl Gustav Jung, Gesammelte Werke, $9 / 2$ (Düsseldorf: Walter-Verlag, 1995).

${ }^{6}$ Idem, Gesammelte Werke, $9 / 1$ (Düsseldorf: Walter-Verlag, 1995)

7 Marie-Louise von Franz, L'interprétation des contes de fées (Paris: Dervy-Livres, 1987).

8 Idem, Les modèles archétypiques dans les contes de fées (Paris: Jacqueline Renard, 1999).
} 
of listeners is the result of the archetypal dimension of fairy tales which resonates with the psychic energy of the unconscious. That is also the reason for which fairy tales are so well remembered. Thus, the emotionally loaded archetypal content of fairy tales can also account for the indignation of listeners (children or adults) when the one who tells the story strays way from the classical text. What is more, the attention paid to the accuracy of the form also unveils the ritual dimension to be found in the tale's origin. ${ }^{9}$

According to Franz, in Europe the most complex texts of fairy tales were meant for adults until the $17^{\text {th }}$ century. In the rural environment, the community adults' practice of listening to fairy tales was preserved until much later. One example in this respect is the Romanian social soirees that are recorded to unfold until the middle of the $20^{\text {th }}$ century. As Franz shows, the association made by contemporary Westerners between children and fairy tales and the inherent simplification incurred by that only shows the little respect they pay to the contents and power of the unconscious. ${ }^{10}$ Concerning all of the above, I believe that the unrestricted unsupervised access of children to the complex archetypal forms of fairy tales ever since their early childhood can partially explain their unsettling rapid development. As for what fairy tales are, each one of them is associated to an archetypal behavioural type. All fairy tales make an intuitive map of the collective unconscious and its structures and processes. 11

Fairy tales provide information on how the compensating function of the unconscious works. As Freud indicated, ${ }^{12}$ the psyche is oriented towards reducing the consumption of energy, namely diminishing and balancing the psychic tensions. It is exactly within the same framework that Jung refers to the compensating function of the unconscious. The latter compensates attitudes, deeds, conscious options meant to ensure efficient integration as part of the individuation process. Fairy tales signal the archetypal tension areas within the unconscious that are responsible for the compensatory outbursts. They also indicate the psychic status of peoples, nations, cultural areas and hence can be used as predictors. The analytical interpretation of fairy tales allows the recording of the undercurrents of the collective unconscious and a correct anchoring in the reality for which they act as compensators. ${ }^{13}$

Fairy tales interpretation is similar to the interpretation of dreams (viewed by Freud as the major path to the unconscious). According to Franz, the interpretation of dreams is a sequence of four stages: dividing the narrative in units of meaning (an approach similar to isolating my themes in the structuralist analysis didactically imposed by Claude LeviStrauss); amplifying outlining of symbols in the order in which they appear in the fairy tale (the amplification refers to highlighting the relation with other cultural artefacts in which the archetypal contents is manifest in a similar/complementary/culturally adapted manner); identifying the contexts in which the symbolic images appear (namely their historical, geographical, ethnic, religious etc. anchoring); the interpretation itself, namely the translation of the fairy tale in psychological language.

As the analyst underline, all interpretations are relative. ${ }^{14}$ They are tributary to the cognitive assimilation threshold employed by the interpreter. Therefore, analytical psychology requires specialists to have comprehensive humanistic training.

\footnotetext{
${ }^{9}$ Ibidem.

${ }^{10}$ Marie-Louise von Franz, La femme dans les contes de fées (Paris: Albin Michel, 1993).

${ }^{11}$ Idem, L'ombre et le mal dans les contes de fées (Paris: Jacqueline Renard, 1990).

12 Sigmund Freud, Die Traumdeutung (Wien: Franz Deuticke 1950).

${ }^{13}$ Franz, L'interprétation.

14 Ibidem.
} 


\section{Whom is the fairy tale about?}

The central characters of fairy tales are heroes. Analytically speaking, the fairy tale hero symbolizes the formative factor of the Ego, namely that part of the Self archetype that is a model and structural foundation for the Ego and which, as such, builds and guarantees the latter's stability. ${ }^{15}$ The fairy tale heroes go on initiation trips at the end of which they come back home wise, rich and triumphant. The trip is an individuation process by which the Ego harmonizes with the Self.

Fairy tales do not perfectly overlay known, conscious, and desirable representations of self accomplishment. This imperfection is due to the resistance raised by the Ego of the listeners/ readers to refocus on the Self, and hence causes dissatisfaction to the listeners or the readers of the fairy tales. The end of classical fairy tales is not always a happy one. Somebody dies (justly punished even though that person could be somebody close to the hero), is mutilated and destined to live like that, etc. Such endings signal the integrative dimension of the Self (which encompasses both the good and the evil) and, more importantly, the continuous endless character of the individuation process in which new, even subtler stages emerge.

The fairy tale heroes are schematic, have no interior substance, and they are not real human persons. The way they are represented unveils their status of archetypal representations.

An Elderly Wise Man is always around many fairy tale heroes. He symbolizes the active power of the collective unconscious that configures, arranges and organizes archetypal images. His role is to intelligently guide heroes to adequately use their available resources. The formative factor of the Ego is guided by the unconscious to use its allocated psychic energy. The presence of the Elderly Wise Man in fairy tales has a correspondent in the prestige given to the elderly in the past: the third age was a test of wisdom and quality, a divine blessing and a criterion to gain extremely important positions in social organization. ${ }^{16}$

The hero is also surrounded and helped by various magic, talking animals. According to Marie-Louise von Franz, there are two categories of animals: real ones and people who are temporarily trapped in an animal's skin. Real animals symbolize instinctual pulsions in fairy tale. Pseudo- animals represent spiritual pulsions retained in the unconscious since they do not match the dominant vision of the world (and which is consciously assumed) when the fairy tale emerged. The dominant features of the animal species in whose skin a person is entrapped indicate, by similitude, the type of human behaviour corresponding to the psychic content that is retained in the unconscious. For example, the male fox in the Saxon fairy tale The Wehmus Bird (I will get back to this tale a little bit later in the text) hides the spirit of nature under his skin, is clairvoyant and cunning, and acts efficiently when it comes to surviving and overcoming the most unusual trials. Such a spiritual pulsion is pushed by the West into the unconscious and therefore, the refusal to marry her is a mistake and bears consequences on the individuation process. It is actually the case with many fairy tales in which the advice of the magic animals is not taken and thus heroes miss to apply solutions supplied by instincts and unconscious.

In fairy tales, heroes interact with various representations of the anima. This aspect is to be detailed further in this text. Moreover, divine children (that is kids who are miraculously born) are present in the fairy tales, as well as marked ones like the brothers with a star on their forehead or children who are made completely out of gold. These are symbols of

\footnotetext{
15 Marie-Louise von Franz, La délivrance dans les contes de fées (Paris: Jacqueline Renard, 1998).

16 Diana-Cristina Bódi, Persoanele vârstnice. Resursă importantă în familie și în societate [Older people. An important resource in family and society], (Iaşi: Institutul European. 2017).
} 
renewal, of the Self that is about to emerge and manifest itself. The surfacing from the unconscious of content that is already assumed by the conscious is uplifting and related to the individuation process.

There are also negative characters around heroes and any reference to them thrusts the question on the narrative dimension of the fairy tale in the limelight.

\section{What do fairy tale characters do?}

I will present several types of fairy tales by their archetypal contents. This is just for supporting the arguments related to the educational and diagnostic role of fairy tales and hence is not an exhaustive endeavour.

\section{Two people travelling through the world}

Some fairy tales provide information on the shadow and the management of assuming it. There are two components of the shadow, as Franz ${ }^{17}$ highlights: a personal one and a collective one, that is related to the group of origin. Even cultural areas have their own shadows. The shadow of contemporary West is focused on some sort of metaphysical ignorance, the result of a long rationalistic education process. it is responsible for the Westerners' appetite for wars, nationalist hat, consumerism, programmatic destruction of nature, indicates Franz.

Fairy tales operate with the collective dimension of the shadow. Not integrating the personal dimension of this archetype favours its inclusion in the collective dimension. The conflict with the shadow can be overcome but not solved. Ethically speaking, archetypes are neutral at the unconscious level. It is only their activation in the consciousness via representations that polarizes them as good - evil in the Western culture. The correct efficient attitude on behalf of the Ego is to acknowledge the existence of the shadow that accompanies the individuation process.

As Franz shows, the issue of the shadow is paradigmatically outlined in the fairy tale by the trip that two persons take around the world and, when they reach the king's court, one of them tries to destroy the other.

Marie-Louise von Franz ${ }^{18}$ analyzes two tales from the Grimm Brothers' collection - The Two Travelers and Ferdinand the Faithful and Ferdinand the Unfaithful - from the perspective of the relationship of the Ego with the shadow.

Ion Creangă's tale Harap-Alb ${ }^{19}$ (Romanian for The White-Negro) is centered on the same issue. The Bald Man is the shadow of the White-Negro. As a fairy tale character, the general features of the hero bear some local traits attributable to the historical experience of the Moldavians with the Tatars. Even the name given by the Bald Man to the hero when making him his slave is representative for the hero's relation with the shadow and for the local option by which to signal it. The name Harap-Alb (contains a semantic contradiction, since the term Harap is used with the meaning of black man. Such a meaning is the result of a semantic juxtaposition of the terms Arab and Black African used in Wallachia and capturing the reality of a historical context when Arabs would trade slaves (some of which black) from the African territories.

\footnotetext{
${ }^{17}$ Marie-Louise von Franz, La voie de l'individuation dans les contes de fées (Paris: Jacqueline Renard, 1978). Idem, La délivrance.

18 Idem, L'ombre.

${ }^{19}$ Ion Creangă, Povești, povestiri, amintiri [Stories, narrations, memories], (Bucharest: Minerva, 1978).
} 


\section{Beautiful girls, princesses, fairies, witches}

Other fairy tales are centred on the relationship of the hero with various aspects of the anima. As Franz shows, the rich manifestations of this archetype in the European fairy tales are due to the need to activate the values of femininity in the unconscious in a compensating manner as a result of a Judeo-Christian culture ${ }^{20}$.

In fairy tales there are princesses kidnapped by dragons and saved by heroes, good and generous fairies guarding the order of the world, and poor and very beautiful girls who make spectacular and hard to ignore promises. The relationships between heroes and them are simple and highlighting. Sometimes, the former benefit from their relations with princesses, who are temporary captive in animal skin, a symbol of spiritual pulsions equivalent to the anima that resides in the unconscious. I will address this kind of relationship later on.

Besides these bright, attractive and quite aspects of the anima, the fairy tales also unveil dangerous dimensions of the feminine principle. Sometimes princesses dance and thus charm the onlookers transforming them into stones (similar to Iele - feminine mythical creatures in Romanian mythology). According to Franz, ${ }^{21}$ dancing is a way by which the Self becomes manifest as a cosmic dance.

Marie-Louize von Franz ${ }^{22}$ comparatively analyzes two fairy tales on the magical and secret dance of the anima: a Danish tale called The Princess with 12 Golden Pairs of Shoes and one from the Grimm Brothers' collection - The Shoes with Holes in the Soles. The Danish fairy tale is about a princess who dances all night and thus tears twelve golden pairs of shoes (a number similar to the number of night hours - the interval of darkness and secrets). Her companions are a troll, who cast a spell on her and the marriage candidates who had already tried to save her. The hero needs to kill the troll before marrying the princess and his intervention is soteriological. He unveils and brings proof of the princess's night trips and thus manages to break the spell and bring back to life the forests of the charmed empire by killing the troll.

The atmosphere of the tale is bleak; the tensions among characters are spectacular, and emotionally loaded. As Franz shows, the Danish tale unveils a people's collective psyche that has not developed a culture of the anima. The weak representation of the feminine is due to the direct overlay of Christianity with the beliefs in the spirits of the Danish areas. The psychic energies of the North European peoples are channelled on trolls personifications of the amazing powers of the mountains, forests, torrents that are in the middle of a primitive religious experience. The trolls' powers lead to possessions and those who are spiritually possesses are dehumanized. By lowering and including ideals into the material world, the dialectic materialism managed to impose such an empire of trolls, suggests Franz. The princess is the archetype of the anima in its nubile dimension that steps into the depths of the unconscious. In the fairy tale there is a ladder to the lower parts of the Earth where the troll rules. The latter's presence indicates that the conscious and unconscious used to be related. Nonetheless, their relationship has been compromised by the early adoption of Christianity in Northern Europe, believes Franz.

The other fairy tale analyzed by Marie-Louise von Franz, The Shoes with Holes in the Soles is pretty similar to Ispirescu's tale The Twelve Emperor's Danghters and their Charmed Palace ${ }^{23}$.

\footnotetext{
${ }^{20}$ Franz, La femme.

21 Idem, Les modèles.

22 Ibidem.

23 Petre Ispirescu, Legendele sau basmenle românilor [Legends or Fairy Tales of Romanians] (Bucharest: Editura pentru Literatură, 1968).
} 
Contrary to the version of the Danish tale, the princesses in these fairy tales are the ones who are willing to dance and their performance bewitches their pretenders in the ball room of the palace. The twelve princesses symbolically exhaust the nubile stages of the anima. The hero's intervention is not a saving act by itself since they are not in suffering. By unveiling the secret of their nocturnal trip the hero manages to naturally assign them with normal dance partners and thus resets that natural order of the world. These fairy tales reveal a much better relationship between the conscious psyche and the feminine principle compared to the Danish one. This good relationship with the feminine principle has a correspondent in the rituals that the nubile girls in the Romanian villages still perform in order to rush their marriage. Traditionally, marriage and birth of children while the woman is young are considered natural and good practices in rural areas. ${ }^{24}$

There are also evil fairies who willingly trouble the good course of the world. There are also witches even more evil than the princesses who bewitch through their dance. The witch in the fairy tale symbolizes the terrifying dimension of the Great Mother archetype. Christianity pushed this archetype into the unconscious by valuing it in a unilateral and positive manner in the representations of the Virgin Mary. It is thus the fairy tales that compensate for ignoring this dimension. The gypsy woman (sometimes accompanied by her mother who is good at enchantments) sneaks in the bedroom of rich man in order to work her evil intentions and thus symbolizes another dark aspect of the anima.

In Ispirescu's tale Inșir-te mărgăritari (Romanian for Pearls, Thread Yourselves) the gypsy servant buries the new born golden babies of her mistress in manure and replaces them with two puppies. Thus, she takes over the role of wife and kids' mother. As such she subjects the children to a number of individuation processes that clearly hint at alchemist transformations (into golden apple trees, blades of basil, pieces of the golden wool lamb of the master, two children playing with golden apples). In the end, the gypsy's deceit is unveiled and she is punished to be torn to pieces that are scattered around the world. The negative and yet catalyzing aspect of the anima is no longer in a projection state and its energy is redistributed.

The dragon from fairy tales whom the hero needs to dare signifies, as Franz ${ }^{25}$ shows, the maternal instinct that lies undifferentiated in the unconscious. The emergence of the individual consciousness involves getting away from the mother, that is killing the dragon.

Returning to the issue of the anima captive in an animal's skin, Marie-Louise von Franz (2016) analyzes a fairy tale called The Cat which was collected in Romania. ${ }^{26}$ This is included in the collection Die Märchen der Weltliteratur, chapter Zigeuner Märchen.

Von Franz does not explicitly indicate the Roma origin of the fairy tale. On the contrary, in her analysis she refers to the historical and cultural roots of the Romanian peasants to whom she attributes its circulation. The latter, the authors states, are under the influence of the Habsburg Empire and hence their fairy tales refer to emperors and not kings. Considering the impressive pagan component of the gypsy culture and as a result of her attribution of this fairy tale to the Romanian peasants, Marie-Louise von Franz fails to explore the special relation that the Roma people have with Virgin Mary, and hence the border line that defines it. Thus, if the text would be attributed to gypsies, and not Romanians, whose majority is made of Orthodox worshippers or Greek Catholic in

\footnotetext{
${ }^{24}$ Mariana Borcoman, "The significance of Saint Andrew's day in Romanian Folklore," in microCad 2008, International Scientific Conference March 20-21 2008, ed. László Lehoczky (Miskolc: University of Miskolc, 2008), 13-17.

25 Franz, La voie.

${ }^{26}$ Idem, The Cat: A Tale of Feminine Redemption (Toronto: Inner City Books, 2001).
} 
Transylvania, the references made to Virgin Mary could be analyzed from a different perspective. What is more, even the theme of the cat woman would be easier to relate to the gypsy folklore, considering the latter's Oriental roots. In this respect, it is worth reminding that sometimes Romanians pejoratively call the Roma people "pharaohs."

All these observations only contribute to a more refined analysis of fairy tale about men and their erotic and potent anima and become relevant in terms of the relationship between fairy tales and the psychological configuration of peoples. According to Marie-Louise von Franz, fairy tales compensate for the dominant psychological attitude to be found with the collective consciousness of a people. Their analysis unveils the layers of the collective unconscious, namely activated archetypes, their prevalent dimensions, the relationship among these and, additionally, the factors in the peoples' psyche that need to acquire balance through fairy tales.

The tale named The Cat is about a princess cursed by Virgin Mary while still unborn to transform into a cat when she turns 17 . The curse is triggered by the offense brought by princess' mother, who could not have any children, to Virgin Mary. Thus, while travelling at sea, the empress steals (actually her servants steal) a golden apple from Virgin Mary's garden. When biting into the apple, she learns that she is six months pregnant. However, her child is not a divine one but a cursed one. The princess grows up into a beautiful and normal girl. When she turns 17, during a family meal, she and her servants turn into cats and leave to the forest. It is a peaceful, non-dramatic departure. The prince who saves her comes from an empire ruled by a widow drunkard emperor. He is the youngest boy of the three the emperor has and meets the cat in her castle in the forest and falls in love. The prince undergoes a number of initiatic trials like physical suffering, nakedness and confronts his father in armed conflict. In the end, the cat, his wife by now, convinces him to cut off her tail and then her head in order to undo the curse and help her regain her human aspect.

This is a fairy tale about the wisdom of anima that helps man evolve and discover it. Moreover, it outlines men's need for the feminine as inspiration, support and facilitator in accomplishing their highest goals. Last but not the least, the tale shows that the feminine easily cooperates with the masculine when it is acknowledged and (at archetypal level) appreciated as such. The cat princess from the fairy tale collected in Romania symbolizes the potentiality of the anima which, when correctly acknowledged and approached can become an ally of men helping them to develop spiritually.

\section{Temporary captivities in an animal's skin}

The fairy tales in which the hero and the heroine, in animal skins, are in love (or establish an erotic relation) are therapeutic, according to Marie-Louise von Franz. ${ }^{27}$ As she shows, these texts supply recipes by which psychic disorders can be overcome. According to popular beliefs, the neuroses and psychoses are consequences of spells and curses. The dramatic emergence from under the skin of an animal signifies the intensely emotional confrontation of consciousness with the unconscious contents that generate the psychological disorder.

Psychic issues that facilitate the access to highly emotional unconscious contents are useful for the individuation process. Their efficient management hurries the end of the latter. Human characters are transformed into animals as a result of spells or curses and their freedom lies at the end of a number of trials and adventures, which analytically speaking, equates their healing.

${ }^{27}$ Franz, La délivrance. 
Fairy tales present extricating instinctive processes that unfold in the human psyche. The liberation process is individual but it overlays the representations of typical healing processes associated with certain diseases that are manifest in the collective unconscious.

Skin burning (symbolizing the confrontation between consciousness and the unconscious content that triggers psychic distress) proves a liberating solution only when it is preceded by efforts that are perceived as embarrassing. Premature burning prolongs the spell or the curse. In the absence of perseverance and consented effort, diseases take new forms and the infantilism of conscious attitudes runs into the risk of recreating the neurotic situation.

Marie-Louise von Franz analyzes as an example of a therapeutic fairy tale a Russian one: The Frog, the Czar's Daughter, and an Italian tale: The Pig Prince. In the Russian story the prince marries to a frog that proves her household related skills and, what is more, performs a number of miracles in front of their wedding guests ending by temporarily abandoning her frog skin and thus unveiling her human face of great beauty. The prince burns his wife's skin but the latter becomes a prisoner in a palace located at the far end of the world. What the husband needs to do is to find the palace and free her.

In the Italian fairy tale one of the fairies predicting people's destiny casts a spell on the prince to live in a pig's skin. When he marries, his first two brides, daughters of a poor perfume maker successively think of killing the groom during the night of the wedding. However, they do not manage to do that and are punished. The third bride, the youngest sister of the two accepts to live with her pig husband who, at night, took human form. After a while the prince's parents come to visit them, find the prince's skin, burn it and thus break the spell. A similar fairy tale of Ion Creangă, The Story of the Pig, ${ }^{28}$ can be considered a combination of the therapeutic liberating ways. ${ }^{29}$ In this story, the ill advised wife burns the skin before the time for doing that and thus needs to go on the liberating trip. However, Creanga's story is about a double liberation. The archetypal fairy tale scenario refers to the constructive meeting between an individual's anima and the animus of his partner. Creangă's story therapeutically approaches one stage from a two-fold individuation process.

\section{The magic healing song}

Some fairy tales are focused on the blockages to the Self that appear during the individuation process. These are similar to those in which the king is sick and the hero needs to find a cure for him. The similarity between these texts and the theme focused on the search of the Grail is obvious. The king symbolizes the dominant representation (accepted at conscious level) of divinity in the cultural area where the fairy tale originated. The king's disease shows that such a representation fails to meet the psychic needs of the individuals from that specific cultural area and from that particular age when the fairy tale is dated. In many tales of this kind, the king feels better if a magic bird sings for him and such a song signifies the healing emergence at conscious level of some messages from the unconscious.

Von Franz ${ }^{30}$ analyzes a Transylvanian Saxon fairy tale of this type called the The Wehmus Bird. "Wehmus" is a phonetic alteration of the word "Phoenix." The story is about a sick

\footnotetext{
${ }^{28}$ Creangă, Povești.

${ }^{29}$ Daniela Sorea, "Complexitatea individuatoarea a vieții de cuplu." [The individuation complexity of the couple's life], in Familia creşstină. Fundamente antropologice, iubire şi sexualitate in celibate și căsătorie [The Christian Family. Antbropological foundations, love and sexuality in celibacy and marriage], eds. Alexandru Buzalic and Călin Ioan Dușe (Cluj-Napoca: Presa Universitară Clujeană, 2016), 249-66.

${ }^{30}$ Franz, La voie.
} 
pastor whose pains calm down when a bird sings to him. From the latter's beak pour down pearls. His sons leave to search for this bird that only spent little time with the sick man. While travelling, the elder sons refuse to share their food with a male fox and without the latter's advice they fail in their search. The youngest son does share his food with the fox and with his help he borrows the bird from the emperor, marries to his youngest daughter and enables the transformation of the fox (who was actually a bewitched prince) into a human being. The pastor's sickness suggests the problems created by the unilateral development of consciousness of middle aged men. An intellectual rationalistic attitude suffocates emotions and spontaneity, reducing the appetite for life. The fairy tale suggests the solution to such a disease by invigoratingly reiterating some vital experiences.

The presence of the pastor signals the religious dimension of the blockage within the individuation process. In this respect, Ispirescu's The Magic Bird, ${ }^{31}$ is structured pretty similarly to the one analyzed by Franz. Instead of a sick shepherd, Ispirescu's story is about a God fearing emperor. He was trying to build a monastery but it kept collapsing. The motive of the collapsing monastery corresponds in the Romanian folklore to the ballad of Manole, the Craftsman and exemplifies the local particularization of archetypal motives. The emperor's sons leave one by one to look for the magic bird that lives in far away land in order to place it in the tower of the monastery and thus enforce the construction. The youngest of them offers the fox food and drink, manages to break the spell cast on the latter and thus acquires a wise and loyal companion for his trip. On the way back home his brothers cut off his feet, take the bird and the girl saved from the dragons' palaces and present themselves to the emperor. The youngest brother reaches back home much later. He is helped by the fox to regain his health and asks for justice. He marries to the saved girl and takes his father's place on the throne. The bird who had been sitting mute in the tower starts singing only when the youngest son comes back home, that is just for the one who had the merit of having truly acquired her. Even Ispirescu's tale suggests a religious blockage by characterizing the emperor as God fearing, as well as via the nature of the building that needs reinforcement.

A muted bird signals the formal dimension of the religious and is but a form without content. However, the tale suggests that forms require struggle to be filled with content.

\section{The two couples}

Other fairy tales are centered on quaternary activating the Self archetype. According to Jung, ${ }^{32}$ one of the symbolic representations of the archetype of the whole is quaternity. This is a balanced relation among four elements built on the ancestrally significant structure of the cross. It is the scheme by which order is achieved without fail, a system of coordinates instinctively used to divide the land, the year, traditional communities, moon phases or temperaments. The idea of quaternity in fairy tales is frequently related to the establishment of two couples: a profane one and a magic one. Children (in pairs - a brother and a sister) marked with a star on their forehead make along with their parents (and as with any patriarchal society the mother needs to first undergo a series of persecutions) a quaternity. Up until the moment this quaternity is whole (namely at the end of the fairy tale when equilibrium is reached) one of the brothers, and usually it is the sister, assumes the role of savour. Thus, the feminine principle, which in the European culture is more closely related to the shadow and the evil than the masculine principle, can, for exactly this reason,

\footnotetext{
${ }^{31}$ Ispirescu, Legendele.

32 Jung, G.W, $9 / 2$.
} 
reconcile the divine with the humane, the spiritual with the terrestrial, the good with the evil, as Franz indicates. ${ }^{33}$

The fairy tale analyzed by Marie-Louise von Franz ${ }^{34}$ about the quaternary activation of the Self is a Spanish one. Its name is The White Parrot. The story joins a lot of themes anchored in archetypes: a woman gives birth to some extraordinary children in the absence of her husband; the parrot, who is considered as the holder of the truth and knowledgeable about future; the spring with silver water and the oak tree with silver and golden fruits - all of which signals the alchemic origin; the old witch; the placement of the unwanted children in a basket and their abandon into the waters of the river. The interpretation proposed by Franz is a complex one and values all these different themes in a differentiated manner. As the analyst shows, from the perspective of Self activation, the children with a star on their forehead seem to favour the shaping of a quaternity where symbols of wholeness are present: the parents, the old fisherman and his wife and finally, the parents again in the presence of the parrot. The latter's presence is a sign of stability of the quaternary structure. The parrot, the fifth element, the quintessence, is in this case a representation of the spirit of knowledge.

Ispirescu's fairy tale Pearls, Thread Yourselves, already approached from the perspective of the dark dimensions of the anima, is focused on the quaternary activity of the Self. However, the Romanian tale does not have several characters like the administrator who is in love with the master's wife, and the witch. These roles are both attributed to the gypsy who causes the metamorphosis of the children. Initially stifled by the warm and germinating manure they rise as golden apple trees and undergo all the traumatic transformations characteristic of the vegetal world. Then, they are subjected to the trials of the animal register and only after they are cut to be served as food they regain their human form. The innovative spiritual pulsions initially manifest themselves at pre-human level and then become operational through awareness.

The emergence of an authentic quaternary representation is the result of exposing the gipsy who, as wife of the master, is sitting next to him and his children - a boy and a girl- in a very active pseudo-quaternity.

The Story of the Pig can be considered a fairy tale centred on the activation of the Self as well. It is more complex than the therapeutic tales like The Frog, the Czar's Daughter and The Pig Prince with which is thematically close. In the case of the Romanian fairy tale the initiation is a two-fold one and overlays the confrontation between consciousness and the unsettling content of the unconscious. The result of these trials is also related to quaternity: the latter consisting of Him - Her- Animus- Anima is formed at the end of the initiation processes of the hero and his wife through the withdrawal of the animus and anima projection. This is also a fairy tale that provides suggestions as to the individuation process incurred by a couple's relation. ${ }^{35}$ Is a type of relationship that Westerners can benefit from: in the couple identity work, femininity and masculinity, although socially constructed as opposite gender identities, could change places or melt into one another in a continuous process, transgressing differences and being united by partners' orientation towards domesticity and intimacy, Rezeanu ${ }^{36}$ highlights.

\footnotetext{
33 Franz, La voie.

34 Ibidem.

35 Daniela Sorea, "Complexitatea”, 249-66.

${ }^{36}$ Cătălina- Ioana Rezeanu, "The relationship between domestic space and gender identity: Some signs of emergence of alternative domestic femininity and masculinity," Journal of Comparative Research in Anthropology and Sociology 6 (2) (2015): 9-29.
} 
The marriage between the emperor's daughter and the pig son of the poor old man takes place in a land that lies beyond the borders of the known world. The couple undergoes a double conversion. The pig proves to be Prince Charming, while the slightly imprudent princess becomes a poor woman undergoing a lot of sorrows; it is only in this moment that the couple can manifest itself in a creative manner. The unfolding of the individuation process is marked by a quaternity based, balanced structuring of couple relations.

The motive of the double marriage also belongs to quaternity. However, when analyzing the Transylvanian fairy tale, The Wehmus Bird, Franz considers it rarely employed. The same motive is to be also found in Ispirescu's story The Magic Bird where the male fox who had been married before the spell was cast on him returns home when the hero marries to the girl he saves from the dragons' palaces.

\section{The educational role of fairy tales}

The enumeration of the types of fairy tales is not exhaustive, and fairy tales operate with groups of archetypal motives. The same story fits from a typological perspective many categories. Such an example already provided in this paper is The Story of the Pig. Nonetheless, different archetypal motives shape individuation processes in the case of all fairy tales.

From an educational perspective, fairy tales unveil their usefulness at least from two perspectives. The hero who undergoes an initiation process returns home victorious, with a thorough knowledge of how the world works, represents an attractive model. The educational approach can explicitly value the heroic dimension of successful schooling. The heroic dimension is enhanced by the use of information technology, which involves "interaction techniques, search reformulation, relevance judgement," as Repanovici points out. ${ }^{37}$

From another perspective, fairy tales are useful as models/suggestions as to how life situations with archetypal resonance can be managed. An adequate luggage of known (available) fairy tales helps individuals find, recognize and trust when in need the efficient archetypal solution. This is not about explicitly looking for solutions to crisis situations in the fairy tale volumes from libraries, but about identifying a known archetypal context from the fairy tale with which the psyche of an individual resonates. Acknowledging an archetypal context, assuming that it involves opening channels to the depth of the psyche, is similar to the diagnosis that the leader of the căluşari from Oltenia makes based on the melodic line with which the patient resonates. ${ }^{38}$

The two-fold usefulness of fairy tales already described above highlights the importance of accessing them in a differentiated manner by age and progressively by their content. Fairy tales are not mere stories to put children asleep. Whether told or read when wide awake or already asleep they manage to connect listeners' psyche to the archetypal reservoir from the collective unconscious. I believe that the traditional choice of the moment when the lesson of the fairy tale is to be conveyed is not at random and proves a thorough knowledge of the psychic works. However, fairy tales do not have the role of putting children at sleep. On the

\footnotetext{
37 Angela Repanovici, "Information Technology Implication in Student Behaviour for Information Literacy Skills," in Education and New Educational Technologies. Proceedings of the 4th WSEAS/LASME International Conference on Educational Technologies (EDUTE'08). Book Series: Recent Advances in Computer Engineering, ed. Nikos E. Mastorakis et al. (WSEAS Press, 2008): 81.

38 Gail Kligman, Calus. Symbolic Transfomation in Romanian Ritual (Chicago: University of Chicago Press, 1981).
} 
contrary, I would argue. Exposure to models is one of the forms that social learning process, which has effects on the formation of attitudes and opinions of social actors, can take. Modeling is exercised, in the first instance, by the family of origin, one of the most important and constant sources of social influence, Gotea says. ${ }^{39}$ The social role undergoes changes according to the context (characterized by affectivity or affective neutrality - from Parsons) in which it is exercised. ${ }^{40}$

Fairy tales fulfil their educational role if they reach the consciousness of individuals by successive and increasingly complex reiterations and starting since childhood. These reiterations outline different dimensions of the archetypal content that can be accessed gradually while growing and being confronted with specific life related situations. The ability of (good) books to seduce readers and to clarify their point of view about life ${ }^{41}$ is related to the archetypal content they convey. Fairy tales do this in the easiest way.

\section{The European role of fairy tales}

As local particularizations of some general human contents (namely archetypes), fairy tales supply the analyst with information on the psychic status of the population from the area where they are collected and age they are dated. This information is useful in the context of globalization of education, which requires cultural sensitivity, the ability to manage differences in customs, values, and traditions from different countries. ${ }^{42}$ It is not only useful in an educational context. The differences between the Danish story and the Romanian one concerning the dance of the anima indicate different manners of establishing relations with the anima in the case of Romanians and Danish people. It is the difference between the princess who is bewitched by the troll and hence under his power (a tell tale sign of how women from the North are like: rather trolls or fairies than human beings who can establish normal human relations, as Franz ${ }^{43}$ shows and, on the other hand, the twelve dancing princesses who do not really want to be saved and who cast their spells through their dance. It is the difference between people of the North and those of Latin origin.

In The White Parrot tale the Spanish earl is horrified to find that his wife has given birth to two black children. In The White-Negro, the names of the hero and of his shadow (the Bald Man) indicate Romanians' ethnic sensitivities historically anchored.

The Wehmus bird from the Saxon tale from Transylvania is a reminder of the Phoenix motif. The magic bird from the Romanian fairy tale is a reference to the bird of the soul who acts as a messenger from the other world and as psychopomp instrument.

By attributing a tale to the gypsies simply because it was collected in Romania changes its interpretation and somewhat alters the amplifying stages by which its symbols are highlighted, as well as the delineation of the context in which the symbolic images appear in the interpretation algorithm.

The detailed analysis of the particularities of this kind provides useful information for managing multicultural contexts and inter-ethnic relations. In the second decade of the $21 \mathrm{st}$

\footnotetext{
39 Mihaela Gotea, Reţeana socială și conflictul marital: constrângeri şi oportunități [Social network and marital conflict: constraints and opportunities] (Cluj-Napoca: Presa Universitară Clujeană, 2014).

40 Atudorei, Emoțiile.

${ }^{41}$ Carmen Adriana Gheorghe, "Books and the Room of One's Own," Book of Abstracts, 6th Summit of the Book, http://www.unitbv.ro/Portals/9/Summit-

Angela/summit/BOOK\%20OF\%20ABSTRACTS.pdf, (accessed November 8, 2017).

${ }^{42}$ Laura Saunders et al., "Culture and Competencies: A Multi-Country Examination of Reference Service Competencies,” Libri 63, no.1 (2013): 33-46, https://doi.org/10.1515/libri-2013-0003.

${ }^{43}$ Franz, Les modèles.
} 
century Europe is marked by the Brexit, the referendum for Catalonia's independence, the success of a nasty right wing campaign in Austria, the fences raised by Hungary to stop immigrants, a high even though not explicitly formulated concern for altering the European comfort with the coming of the refugees from the Arab world. As Bolborici ${ }^{44}$ highlights, the European Union is not faced with individual requests for refugee placement which would impose a normal flow rate of processing without pressure on European Union borders, or with a transparent refugee process that could be administratively controlled by Member States, the European institutions face a massive exodus of populations from different areas, for different reasons, a phenomenon that happens suddenly in the crushing waves of immigrants and which has no estimate of ending soon.

All of the above shows a disregard for the programmatic values underpinning the generous European project and could be explained by the increased focus on the conscious dimension of European's psyche that has been rationally educated. The European Union is a rational project. Programmatically, public reason prevails in making decisions and resolving conflicts in its area ${ }^{45}$ and "preventing and settling conflictual aspects is based on the coordinating, not subordinating character of international law." 46 Ignoring the unconscious pulsions has led, in this case, to compensatory outbursts.

In such a context, the analytical interpretation of Europeans' fairy tales, the inventory of their common themes and local and ethnic variations must be reconsidered. A detailed map of the local projections of the archetype of the shadow in Europe would ease the management of the complicated European neighbourhood relations, as well as of the nontraumatic acceptance of the refugee influx. A collective identity seems easier to set up nowadays on the basis of problems to be solved than on the basis of a common principle. ${ }^{47}$ The thorough knowledge disseminated via fairy tales can be retrieved in order to support, defend, and balance the common European project.

\section{Conclusions}

The previously mentioned fairy tales belong to different peoples from the European area. Besides the cultural and ethnic differences that are analytically outlined, fairy tales unveil the common archetypal core of the psyche in highly accessible language. The fairy tale relays information on the individuation process from the collective unconscious. It is therefore a simple and efficient "training" means for undergoing individuation.

Fairy tales provide models of individuation based evolution and information on the correct management, from an archetypal perspective, of the significant trials raised to selfaccomplishment. The fairy tale hero is the best of the exemplary models by which the Ego functions in harmony with the psyche since he originates in the fundamental structures of the psyche.

\footnotetext{
44 Ana-Maria Bolborici, "The immigration crisis - reflections concerning the crisis of European identity," Bulletin of the Transilvania University of Brasov, Series VII: Social Sciences and Law 9 (58), no. 1(2016): 39-46.

${ }^{45}$ Gabriela Rățulea, "Introducere.” [Indroduction], in Justiție și coęịune socială [Justice and Social Cohesion], ed. Gabriela Răţulea (Iaşi: Institutul European, 2015), 7-33.

${ }^{46}$ Carmen Adriana Gheorghe, "The Banking Surveillance of N.B.R.- A component of International Regulations," Bulletin of the Transilvania University of Brasov, Series VII Social Sciences, Law 8 (57) no.1 (2015): 161.

${ }^{47}$ Ionuț Mihai Popescu, "Credința şi coeziunea socială în contextul destrămării identităților colective." [Faith and social cohesion in the context of the breakdown of collective identities]. In Justiție şi coeziune socială [Justice and Social Cohesion] , ed. Gabriela Răţulea (Iași: Institutul European, 2015), 227-58.
} 
Fairy tales also supply instruments to defuse tensions among neighbourhoods and harmonize the relations among Europeans and between the latter and their guests.

Fairy tales are a resource. To ignore it is counter-productive since its responsible, professional and undistorted use is less costly.

\section{References}

Bódi, Diana- Cristina. Persoanele vârstnice. Resursă importantă în familie şi în societate [Older people. An important resource in family and society]. Iași: Institutul European. 2017.

Bolborici, Ana-Maria. "The immigration crisis - reflections concerning the crisis of European identity." Bulletin of the Transilvania University of Brasov, Series VII: Social Sciences and Law 9 (58), no. 1(2016): 39-46.

Borcoman, Mariana. "The significance of Saint Andrew's day in Romanian Folklore." In microCad 2008, International Scientific Conference March 20-21 2008, ed. László Lehoczky, 13-7. Miskolc: University of Miskolc, 2008.

Creangă, Ion. Povești, povestiri, amintiri [Stories, narrations, memories]. Bucharest: Minerva, 1978.

Franz, Marie-Louise von. La voie de l'individuation dans les contes de fées. Paris: Jacqueline Renard, 1978. L'interprétation des contes de fées. Paris: Dervy-Livres, 1987. L'ombre et le mal dans les contes de fées. Paris: Jacqueline Renard, 1990. La femme dans les contes de fées. Paris: Albin Michel, 1993. La délivrance dans les contes de fées. Paris: Jacqueline Renard, 1998. Les modèles archétypiques dans les contes de fées, Paris: Jacqueline Renard, 1999. The Cat: A Tale of Feminine Redemption. Toronto: Inner City Books, 2001.

Freud, Sigmund. Die Traumdeutung. Wien: Franz Deuticke 1950.

Gheorghe, Carmen Adriana. "Books and the Room of One's Own." Book of Abstracts, 6th Summit of the Book. http://www.unitbv.ro/Portals/9/Summit-

Angela/summit/BOOK\%20OF\%20ABSTRACTS.pdf. (accessed November 8, 2017).

Gheorghe, Carmen Adriana. "The Banking Surveillance of N.B.R.- A component of International Regulations." Bulletin of the Transilvania University of Brasov, Series VII Social Sciences and Law 8 (57) no.1 (2015): 161.

Gotea, Mihaela. Reţeana socială şi conflictul marital: constrângeri și oportunități [Social network and marital conflict: constraints and opportunities]. Cluj-Napoca: Presa Universitară Clujeană, 2014.

Ispirescu, Petre. Legendele sau basmenle românilor. Bucharest: Editura pentru Literatură, 1968. Jung, Carl Gustav. Gesammelte Werke, 8. Düsseldorf: Walter-Verlag, 1995. Gesammelte Werke, 9/1. Düsseldorf: Walter-Verlag, 1995. Gesammelte Werke, $9 / 2$ (Düsseldorf: Walter-Verlag, 1995).

Kligman, Gail. Calus. Symbolic transfomation in Romanian ritual. Chicago: University of Chicago Press, 1981.

Palmer, Michael. Freud and Jung on Religion. London: Routledge, 1997.

Popescu, Ionuț Mihai. "Credința și coeziunea socială în contextul destrămării identităților colective." [Faith and social cohesion in the context of the breakdown of collective identities]. In Justiție și coezৃiune socială [Justice and Social Cohesion] , ed. Gabriela Rățulea, 22758. Iaşi: Institutul European, 2015.

Rățulea, Gabriela. "Introducere. ” [Indroduction]. In Justiție și coeriune socială [Justice and Social Cobesion], ed. Gabriela Rățulea, 7-33), Iași: Institutul European, 2015.

Repanovici, Angela. "Information Technology Implication in Student Behaviour for Information Literacy Skills,". In Education and New Educational Technologies. Proceedings of the 4th WSEAS/LASME International Conference on Educational Technologies (EDUTE'08). Book 
Series: Recent Advances in Computer Engineering, ed. Nikos E. Mastorakis et al., 81-6. WSEAS Press, 2008.

Rezeanu, Cătălina- Ioana. "The relationship between domestic space and gender identity: Some signs of emergence of alternative domestic femininity and masculinity." Journal of Comparative Research in Anthropology and Sociology 6 (2) (2015): 9-29.

Saunders Laura, Serap Kurbanoglu, Mary Wilkins Jordan, Joumana Boustany, Brenda Chawner, Matylda Filas, Ivana Hebrang Grgic et al. "Culture and Competencies: A MultiCountry Examination of Reference Service Competencies." Libri 63, no.1 (2013): 33-46, https://doi.org/10.1515/libri-2013-0003.

Sorea, Daniela. "Complexitatea individuatoarea a vieții de cuplu." [The individuation complexity of the couple's life]. In Familia creștină. Fundamente antropologice, iubire și sexualitate in celibat și căsătorie [The Christian Family. Anthropological foundations, love and sexuality in celibacy and marriage], eds. Alexandru Buzalic and Călin Ioan Dușe, 249-66. Cluj-Napoca: Presa Universitară Clujeană, 2016.

Stevens, Anthony. On Jung. London: Routledge, 1990. 